Access this article online

Website:

onbt.scholasticahq.com

DOI:

10.18639/ONBT.2017.04.435569

\section{KAI-1 and p53 expression in odontogenic cysts: An immunohistochemical (IHC) marker study}

\author{
${ }^{1}$ Namrata N. Patil; ${ }^{2}$ Abhishek Singh Nayyar; ${ }^{3}$ Vijay Wadhwan; ${ }^{4}$ Minal Chaudhary
}

${ }^{1}$ Department of

Oral Pathology and Microbiology,

Saraswati-Dhanwantari Dental College and Hospital and PostGraduate Research Institute, Parbhani, Maharashtra, India,

${ }^{2}$ Department of Oral Medicine and Radiology, SaraswatiDhanwantari Dental College and Hospital and Post-Graduate Research Institute, Parbhani, Maharashtra, India, ${ }^{3}$ Department of Oral Pathology and Microbiology, Subharti Dental College and

Hospital, Meerut,

Uttar Pradesh, India,

${ }^{4}$ Department of

Oral Pathology and Microbiology, Sharad Pawar Dental College and Hospital, Wardha,

Maharashtra, India

Address for correspondence:

Dr. Abhishek Singh Nayyar, 44, Behind Singla

Nursing Home, New

Friends' Colony, Model Town, Panipat-132 103,

Haryana, India.

E-mail: singhabhishekndls@gmail.com Phone No.: +91-98509 04067

Submission: 25-01-2017 Accepted: 14-03-2017

\title{
Abstract:
}

Background: KAI-1/CD82 is a tumour suppressor gene; decreased gene expression is associated with the increased invasive ability of oral squamous cell carcinoma (OSCC), as hypothesised for various odontogenic cysts and tumours. p53 protein functions in the G1-S phase of the cell cycle to allow repair of the damaged DNA. In the present study, p53 and KAl-1 expression was investigated by using monoclonal antibodies in the various odontogenic cysts. Aims: To detect KAl-1 and p53 expression in radicular cysts, dentigerous cysts and odontogenic keratocysts (OKCs) and to assess the relation between p53 and KAl-1 expression in the aforementioned cysts. Materials and Methods: The present study included histopathologically diagnosed cases of radicular cysts, dentigerous cysts and OKCs for the expression of KAl-1 and p53 antibodies. Results: Amongst odontogenic cysts, radicular cysts expressed a maximum positivity of KAl-1 (20.92\%) while p53 positive cells were maximum in odontogenic keratocysts (4.04\%). The correlation between KAI-1 and p53 expression in the various odontogenic cysts was not found to be significant. Conclusion: The increased KAl-1 expression in the radicular cysts and its downregulation in OKCs may be indicative of aggressive clinical behaviour and the fact that OKCs are hypothesised as neoplastic rather than being developmental in origin.

Key words:

KAI-1, p53, odontogenic cysts

\section{Introduction}

1 he term "cyst" is derived from the Greek word "Kystis," which means "bladder" or "sac." Kramer has defined cyst as "a pathological cavity having fluid, semi-fluid, or gaseous contents and which is not created by the accumulation of pus." Most cysts, but not all, are lined by epithelium. Like epithelium from elsewhere in the body, pathologic changes can and do occur within the cystic epithelium. ${ }^{[1]}$ Odontogenic cysts are defined as those cysts that arise from the enamel organ or its remnants. Odontogenic cysts are lined by the epithelium derived from the remnants of the tooth-forming organ, cell rests of Malassez, glands of Serres (cell rests of dental lamina), reduced enamel epithelium and sometimes the basal cell layers of the oral epithelia. During and after odontogenesis, these cell remnants remain as a common source of cystic changes within the jaw bones. ${ }^{[2,3]}$ It is thought that the epithelial lining of developmental odontogenic cysts has more proliferative potential than the epithelial lining of inflammatory cysts. Radicular cysts are the most common type of cysts of inflammatory origin (about $52.3 \%$ of all diagnosed jaw cysts), which occur due to the effects of inflammation on epithelial remnants (the cell rests of Malassez) situated in the apical portion of the periodontal ligament. Dentigerous cysts, on the other hand, are the most common developmental odontogenic cysts making up to $16.6 \%$ of all the jaw cysts reported. These cysts are associated with the crown of an impacted tooth caused by fluid accumulation between the reduced enamel epithelium and the enamel surface. Histologically, the cyst wall, in dentigerous cysts, is composed of connective tissues lined by low cuboidal, stratified squamous epithelium of two-to-three cell-layer thickness; however, in the presence of inflammation, the thickness of the lining is bound to vary. Odontogenic keratocysts (OKCs) represent $11.2 \%$ of all

This is an open access article distributed under the terms of the Creative Commons Attribution-NonCommercial-ShareAlike 3.0 License, which allows others to remix, tweak, and build upon the work non-commercially, as long as the author is credited and the new creations are licensed under the identical terms.

How to cite this article: Patil NN, Wadhwan $\mathrm{V}$ Chaudhary M, Nayyar AS. KAI-1 and p53 expression in odontogenic cysts: An immunohistochemical (IHC) marker study. Oncobiol Targets 2017;4:12. 
developmental odontogenic cysts and are thought to arise from the derivatives of embryologic dental lamina or its remnants (glands of Serres) and from the extensions of basal cells from the overlying epithelium. Histologically, they are characterized by a regular epithelial lining of parakeratinisedstratified squamous epithelium, which is thin, ranging from six-to-ten cell-layer thickness and with a well-defined basal layer composed of columnar or cuboidal cells. ${ }^{[1-3]}$ OKCs are aggressive cystic lesions that have a tendency to recur if not adequately treated and grow larger than other cysts with a mitotic activity observed in their epithelial lining, which is more than that observed in dentigerous and radicular cysts. ${ }^{[4-6]}$

Genetic and molecular events underlying the development of metastasis have been studied extensively in the past. KAI-1 is a tumour suppressor gene that is inversely related to the progression and invasion of several tumours (metastasis) as was observed by Guo et al., who found the upregulation of KAI-1 in early pancreatic carcinoma with its decreased expression in the presence of metastasis. ${ }^{[7]} \mathrm{Wu} \mathrm{Q}$ identified the role of KAI-1 in digestive tract carcinomas and predicted it to be a useful predictor of prognosis. ${ }^{[8]}$ Farhadieh $\mathrm{RD}^{[9]}$ and Imai $\mathrm{Y}^{[10]}$ identified the role of KAI-1 in oral squamous cell carcinoma (OSCC) and suggested a decreased gene expression being associated with an increased invasive ability of OSCC. The expression of KAI-1/CD82 gene, inversely related to tumour progression, can, thus, be taken as a favourable prognostic indicator. ${ }^{[11]}$

At present, a number of oncogenes and tumour suppressor genes, including p53, RAS, $\beta$-catenin and PTEN, have been implicated in various cancers. ${ }^{[12,13]}$ p53 protein is a product of the tumour suppressor gene p53, which functions in the G1-S phase of the cell cycle to allow repair of the damaged DNA and to prevent the cell from entering the $S$ phase or, alternatively, to guide the damaged cells to apoptosis. ${ }^{[14-18]}$ Also, the high recurrence rate and clinically aggressive behaviour of OKCs have made several investigators study its cause, and the expressions of KAI-1 and p53 protein in OKCs have remained one of the most sought topics in this regard, assuming it to be associated with cell proliferation in OKCs. ${ }^{[19,20]}$ The aforementioned features in these cysts have also caused several authors to consider them as benign neoplasms rather than cysts. ${ }^{[5,21-23]}$ In the recent WHO classification (2005) of odontogenic cysts and tumours, OKCs have been classified under benign tumours arising from the epithelium, and they have been renamed as keratinizing cystic odontogenic tumours. ${ }^{[21]}$

The expression of KAI-1 is supposed to decrease in cancer cell lines, also OSCC. Cancer cells expressing KAI-1 attach to vascular endothelial cells through direct interaction between KAI-1 and DAR (an endothelial cell surface protein), leading to inhibition of tumour cell proliferation and induction of senescence. ${ }^{[22,23]}$ The tumour metastasis is suppressed mainly by an inhibition of cancer cell motility and invasiveness. ${ }^{[1,24-26]}$

As OKCs have recently been categorized as benign neoplasms with high recurrence rates as high as $60 \%,[5,21-23]$ an attempt was made to explain the differences on the basis of their expression of KAI-1 and p53. In the present study, immunohistochemistry for KAI-1 and p53 was employed to evaluate the cell proliferation and aggressive behaviour in radicular, dentigerous and OKCs. There are not many studies conducted in relation to odontogenic cysts, and this was first of its kind. Before this, the expression of KAI-1 ad p53 had been studied in relation to various malignancies. So, this study was designed to investigate the expression of KAI-1 ad p53 in odontogenic cysts and, in particular, to get an explanation for the neoplastic behaviour of OKCs-whether any correlation existed.

In the present study, p53 and KAI-1 expression was investigated by using monoclonal antibodies in various odontogenic cysts. This study is aimed to compare the expression of the aforementioned genes in odontogenic cysts, comparing the clinical implications as against OSCC, a condition wherein the expression of the aforementioned genes is found has already been discussed in detail with various hypotheses proposed as the possible role they might have in OSCC.

\section{Materials and Methods}

An immunohistochemical study was carried out for the evaluation of KAI-1 and p53 expression in the various odontogenic cysts, which comprised radicular cysts, dentigerous cysts and OKCs. Paraffin-embedded sections were obtained. The study sample consisted of 30 cases of radicular cysts, 27 cases of dentigerous cysts, 37 cases of OKCs and 10 cases of normal buccal mucosa. The immunohistochemically stained tissue sections were evaluated by counting approximately 1000 cells in a high-power field wherever possible. The tissues that yielded insufficient epithelial lining as in some of the cases of dentigerous cysts, the total numbers of cells were counted and the labelling index was obtained. Staining was observed as nuclear and cytoplasmic membrane staining. Tissue sections positive for KAI-1 and p53 were examined for the presence of brown, stained cytoplasm and were evaluated by locating the epithelial linings most heavily labeled by scanning the sections at a $100 \times$ magnification. Cell counts were made at $400 \times$ magnification with a conventional light microscope in five randomly selected fields. KAI-1 and p53 labeled cell counting was done amongst all groups. The constituent cells of the lining epithelium were divided into basal, suprabasal/intermediate and surface layers. Cuboidal/columnar cells located in one row at the basement membrane were considered as the basal layer. The surface layer constituted the flattened or polygonal cells consisting of one to five layers, localized just underneath the surface of the lining epithelium. The suprabasal/intermediate layer was composed of relatively large round cells between the basal and surface layers. The number of positively stained nuclei was expressed as a percentage of the total number counted for individual layer and in complete epithelium.

$$
\text { KAI-1/p53 labelling index }=\frac{\begin{array}{c}
\text { Number of IHC positive cells } \\
(\mathrm{KAI}-1 / \mathrm{p} 53) \times 100
\end{array}}{\text { Total number of cells observed }}
$$


KAI-1 expression in the epithelium was converted into a score defined by Farhadieh RD et al. ${ }^{[9]}$ with score 1 assigned for $<10 \%$ of cells with positive staining, 2 for $11-30 \%$, 3 for $31-50 \%$ and 4 for $>51 \%$ of the total number of cells with positive staining. The cells that were positive for KAI-1 expression were divided according to their scores.

The study was approved by the Institutional Ethics Committee before the commencement of the study. The results were presented in two sections with the detailed analysis of KAI-1 expression as descriptive statistics and significant differences in the group. Similar results were applied for p53 expression, and the statistical analysis was carried out.

Principle of immunohistochemical staining: Sections were hydrated with increasing grades of alcohol and brought to distilled water and treated with hydrogen peroxide $\left(\mathrm{H}_{2} \mathrm{O}_{2}\right)$ to eliminate endogenous peroxidase activity. The tissues were then incubated sequentially with the following:

- Primary antibody (KAI-1, C-16, sc-1087, primary antibody, rabbit polyclonal antihuman antibody, Santa Cruz Biotechnology, Inc., p-53, clone DO-7, primary antibody, mouse monoclonal antihuman antibody, DAKO) binds to specific tissue antigens.

- Secondary antibody (biotinylated secondary antibody, DAB chromogen, DAB substrate buffer, haematoxylin, DAKO) binds to the primary antibody; it is a polyvalent antibody that will bind to primary antibodies derived from rabbit, mouse, rat and guinea pig.

- The addition of peroxidase substrate (hydrogen peroxidase) and chromogen results in the formation of a coloured precipitate at the tissue antigen sites. Counter staining with haematoxylin aided in visualization. Positive and negative controls: Normal oral mucosa samples showing KAI-1 labelling for $\mathrm{p}-53$ expression acted as a positive control. One positive control was included for each immunohistochemical cohort. One section from each positive control was used as a negative control by omitting the primary antibody and by incubating with tris-buffered saline (TBS).

\section{Statistical Analysis}

Statistical analysis was performed with the SPSS (version 13, SPSS Inc., Chicago, USA) package. The statistical tests used for the analysis of the results include the following:

- Descriptive statistical analysis

- One-way ANOVA

- LSD

- Chi-square test for intergroup comparisons

- Independent t-test

\section{Results}

KAI-1 counts were observed in decreasing order in the normal buccal mucosa with a mean of $24.28( \pm 4.15)$, followed by radicular cysts with a mean of $20.92( \pm 4.68)$, dentigerous cysts with a mean of $18.38( \pm 4.17)$ and OKCs with a mean of $11.01( \pm 13.01)$. Descriptive statistics was also performed for the expression of p53 in the aforementioned cysts and control groups. Statistically significant variations of means of p53 labelling indices were found amongst all groups. p53 counts were observed in decreasing order in OKCs with a mean of $4.04( \pm 4.13)$, normal buccal mucosa $3.44( \pm 2.32)$, radicular cysts $0.45( \pm 0.72)$ and dentigerous cysts $0.16( \pm 0.37)$. A one-way analysis of variance (ANOVA) showed a highly significant variation $(P=0.00)$ of the mean squares 4104.89 between groups and 128.66 within groups with the degree of freedom between groups $(\mathrm{df}=4.00)$ and within groups $(\mathrm{df}=129.00)$ in the case of KAI-1 expression in the epithelium of radicular cysts, dentigerous cysts, OKCs and normal mucosa. The F-value of 31.91 was obtained showing that statistically significant variations of means of the labelling indices were found amongst all the groups [Table 1]. ANOVA in the case of p53 expression in the epithelium of radicular cysts, dentigerous cysts, OKCs and normal buccal mucosa also revealed a highly significant variation $(P=0.00)$ of the mean squares $20,266.40$ between groups and 49.07 within groups with the degree of freedom between groups $(\mathrm{df}=4.00)$ and within groups $(\mathrm{df}=$ 129.00) [Table 1]. The least significant difference (LSD) post-hoc test for KAI-1 expression in radicular cysts, dentigerous cysts, OKCs and normal buccal mucosa also came out to be highly significant in all the compared groups except between the expression in radicular and dentigerous cysts, radicular cysts and normal buccal mucosa and dentigerous cysts and normal buccal mucosa $(P>0.05)$ [Table 2]. The LSD post-hoc test in the case of $\mathrm{p} 53$ expression was though not found to be significant in the compared groups with $P>0.05$ [Table 3]. $100 \%$ positivity was noted for KAI-1 expression in radicular and dentigerous cysts while OKCs showed a positivity in 22 (59.45\%) of the cases, and 15 cases were found to be negative for KAI- 1 staining. There were significant differences observed in radicular and dentigerous cysts and OKCs. Regarding p53 expression, 10 cases of radicular cysts out of 30, 6 of dentigerous cysts and 31 of OKCs were positive $(83.78 \%)$. OKCs showed the highest positivity of $83.78 \%$ as compared to radicular and dentigerous cysts, which showed a positivity of 33.33 and $22.22 \%$, respectively. Also, KAI-1 and p53 expressions were compared between each group and were found statistically significant $(P=0.00)$ [Table 4].

Table 1: One-Way ANOVA for KAl-1 and p53 expression in the epithelial lining of radicular cysts, dentigerous cysts, OKCs and normal buccal mucosa

\begin{tabular}{|c|c|c|c|c|c|}
\hline \multicolumn{6}{|c|}{ ANOVA } \\
\hline $\mathrm{KAl}-1$ & $\begin{array}{c}\text { Sum of } \\
\text { squares }\end{array}$ & $\mathrm{df}$ & $\begin{array}{l}\text { Mean } \\
\text { square }\end{array}$ & $\mathrm{F}$ & $P$-value \\
\hline $\begin{array}{l}\text { Between } \\
\text { groups }\end{array}$ & $16,419.58$ & 4.00 & 4104.89 & 31.91 & $<0.001^{\star *}$ \\
\hline Within groups & $16,596.84$ & 129.00 & 128.66 & & \\
\hline \multicolumn{6}{|c|}{ ANOVA } \\
\hline p53 & $\begin{array}{c}\text { Sum of } \\
\text { squares }\end{array}$ & df & $\begin{array}{l}\text { Mean } \\
\text { square }\end{array}$ & $\mathrm{F}$ & $P$-value \\
\hline $\begin{array}{l}\text { Between } \\
\text { groups }\end{array}$ & $81,065.60$ & 4.00 & $20,266.40$ & 413.00 & $<0.001^{* *}$ \\
\hline Within groups & 6330.18 & 129.00 & 49.07 & & \\
\hline
\end{tabular}


Table 2: LSD post hoc test analysis between KAl-1 expression in radicular cysts, dentigerous cysts, OKCs and normal buccal mucosa

\begin{tabular}{|c|c|c|c|c|c|c|}
\hline \multirow[t]{2}{*}{ Variable 1} & \multirow[t]{2}{*}{ Variable 2} & \multirow[t]{2}{*}{ Mean } & \multirow[t]{2}{*}{$\begin{array}{l}\text { Std. } \\
\text { error }\end{array}$} & \multirow[t]{2}{*}{$P$-value } & \multicolumn{2}{|c|}{$\begin{array}{l}95 \% \text { Confidence } \\
\text { interval (Cl) }\end{array}$} \\
\hline & & & & & $\begin{array}{l}\text { Upper } \\
\text { bound }\end{array}$ & $\begin{array}{l}\text { Lower } \\
\text { bound }\end{array}$ \\
\hline $\begin{array}{l}\text { Radicular } \\
\text { cysts }\end{array}$ & $\begin{array}{l}\text { Dentigerous } \\
\text { cysts }\end{array}$ & 2.54 & 3.01 & 0.40 & -3.41 & 8.49 \\
\hline $\begin{array}{l}\text { Radicular } \\
\text { cysts }\end{array}$ & $\begin{array}{l}\text { Normal } \\
\text { buccal } \\
\text { mucosa }\end{array}$ & 9.91 & 2.79 & $<0.001^{* *}$ & 4.40 & 15.42 \\
\hline $\begin{array}{l}\text { Dentigerous } \\
\text { cysts }\end{array}$ & OKCs & -3.36 & 4.14 & 0.42 & -11.55 & 4.84 \\
\hline $\begin{array}{l}\text { Dentigerous } \\
\text { cysts }\end{array}$ & $\begin{array}{l}\text { Normal } \\
\text { buccal } \\
\text { mucosa }\end{array}$ & 7.37 & 2.87 & $0.01^{*}$ & 1.69 & 13.05 \\
\hline OKCs & $\begin{array}{l}\text { Normal } \\
\text { buccal } \\
\text { mucosa }\end{array}$ & -5.90 & 4.20 & 0.16 & -14.21 & 2.41 \\
\hline
\end{tabular}

Table 3: LSD post-hoc test analysis between p53 expression in radicular cysts, dentigerous cysts, OKCs and normal buccal mucosa

\begin{tabular}{|c|c|c|c|c|c|c|}
\hline \multirow[t]{2}{*}{ Variable 1} & \multirow[t]{2}{*}{ Variable 2} & \multirow[t]{2}{*}{ Mean } & \multirow[t]{2}{*}{$\begin{array}{l}\text { Std. } \\
\text { error }\end{array}$} & \multirow[t]{2}{*}{$P$-value } & \multicolumn{2}{|c|}{$\begin{array}{c}95 \% \text { Confidence } \\
\text { interval }(\mathrm{Cl})\end{array}$} \\
\hline & & & & & $\begin{array}{l}\text { Upper } \\
\text { bound }\end{array}$ & $\begin{array}{l}\text { Lower } \\
\text { bound }\end{array}$ \\
\hline $\begin{array}{l}\text { Radicular } \\
\text { cysts }\end{array}$ & $\begin{array}{l}\text { Dentigerous } \\
\text { cysts }\end{array}$ & 0.28 & 1.86 & 0.88 & -3.39 & 3.96 \\
\hline $\begin{array}{l}\text { Radicular } \\
\text { cysts }\end{array}$ & $\begin{array}{l}\text { Normal } \\
\text { buccal } \\
\text { mucosa }\end{array}$ & -2.99 & 2.56 & 0.24 & -8.05 & 2.07 \\
\hline $\begin{array}{l}\text { Dentigerous } \\
\text { cysts }\end{array}$ & OKCs & -3.88 & 1.77 & 0.03 & -7.39 & -0.37 \\
\hline $\begin{array}{l}\text { Dentigerous } \\
\text { cysts }\end{array}$ & $\begin{array}{l}\text { Normal } \\
\text { buccal } \\
\text { mucosa }\end{array}$ & -3.27 & 2.59 & 0.21 & -8.40 & 1.86 \\
\hline OKCs & $\begin{array}{l}\text { Normal } \\
\text { buccal } \\
\text { mucosa }\end{array}$ & 0.61 & 2.50 & 0.81 & -4.33 & 5.55 \\
\hline
\end{tabular}

\section{Discussion}

Odontogenic cysts comprise an unusually diverse group of lesions because odontogenesis is a complicated process in which cells in various stages of differentiation participate in a complex, predetermined manner, constituting a group of frequent intra-osseous lesions in the jaw bones. ${ }^{[1-3]}$ Unlike radicular and dentigerous cysts, OKCs can assume a clinically aggressive and destructive behaviour. ${ }^{[4,5]}$ If inadequately treated, these cysts cause considerable expansion within and damage the jaw bones. A significant clinical problem is the high recurrence rate $(12.65 \%)$ observed following surgical enucleation in these cysts. ${ }^{[6,19]}$

When a cyst grows, multiple cytokines are liberated, such as interleukins (ILs), tumour necrosis factor (TNF), matrix metalloproteinases (MMPs), tenascin, fibronectin and parathyroid hormone-related proteins (PTH-rPs), which modulate the function of other cell types and are involved in cellular immune and inflammatory responses via auto- and para-crine signalling, leading to extensive bone damage. ${ }^{[24]}$ OKCs are characterized by their epithelial lining that has some intrinsic growth potential, added to which is the inflammation that alters not only the morphology but also the proliferative potential of the epithelial lining. ${ }^{[1,25]}$ Keratinocytes synthesise IL-1 and IL-6, and these cytokines and TNF account for the raised levels of PGs and collagenase synthesis by uninflamed cystic linings. Also, PTH-rPs have been hypothesised to be expressed in high levels in OKCs and to play a possible role in the growth of these cysts and bone resorption seen by acting synergistically with IL-1. ${ }^{[24]}$ Different markers like proliferating cell nuclear antigens (PCNAs), p53, Ki-67 and silver nucleolar organiser regions (AgNoR) have been studied in odontogenic cysts with PCNAs denoting aggressiveness in such lesions and their potential to proliferate. ${ }^{[26,27]}$ One of the newest markers studied in odontogenic cysts is KAI-1. ${ }^{[28]}$ KAI-1 has been detected in normal human tissues and is a regulator of cell behaviour. The expression of KAI-1 has been seen to decrease in cancer cell lines with high propensity for metastasis. ${ }^{[9-12]}$ Cancer cells expressing KAI-1 attach to vascular endothelial cells through direct interaction between KAI-1 and DAR (an endothelial cell surface protein), leading to inhibition of tumour cell proliferation and induction of

Table 4: Comparison between KAl-1 and p53 expression in different groups by independent t-test

\begin{tabular}{|c|c|c|c|c|c|c|c|c|}
\hline \multirow[t]{2}{*}{ Sample } & \multirow[t]{2}{*}{ Variables } & \multirow[t]{2}{*}{ Mean } & \multirow[t]{2}{*}{ Std. deviation } & \multirow{2}{*}{$\begin{array}{c}\text { Std. error } \\
\text { mean }\end{array}$} & \multirow[t]{2}{*}{$t$} & \multirow[t]{2}{*}{$P$-value } & \multicolumn{2}{|c|}{ 95\% Confidence interval (CI) } \\
\hline & & & & & & & Lower bound & Upper bound \\
\hline \multirow[t]{2}{*}{ Radicular cysts } & $\mathrm{KAI}-1$ & 20.92 & 4.68 & 0.86 & 23.66 & $<0.001^{\star *}$ & 18.71 & 22.24 \\
\hline & p53 & 0.45 & 0.72 & 0.13 & & & & \\
\hline \multirow[t]{2}{*}{ Dentigerous cysts } & $\mathrm{KAI}-1$ & 18.38 & 4.17 & 0.80 & 22.59 & $<0.001^{* *}$ & 16.56 & 19.87 \\
\hline & p53 & 0.16 & 0.37 & 0.07 & & & & \\
\hline \multirow[t]{2}{*}{ OKCs } & $\mathrm{KAI}-1$ & 11.01 & 13.01 & 2.14 & 3.10 & $<0.001^{\star *}$ & 2.44 & 11.49 \\
\hline & p53 & 4.04 & 4.13 & 0.68 & & & & \\
\hline \multirow[t]{2}{*}{ Normal buccal mucosa } & $\mathrm{KAl}-1$ & 24.28 & 4.15 & 1.31 & 13.86 & $<0.001^{* *}$ & 17.62 & 24.06 \\
\hline & p53 & 3.44 & 2.32 & 0.74 & & & & \\
\hline
\end{tabular}

**Highly significant at $P<0.001$. 
senescence. ${ }^{[22,23]}$ The tumour metastasis is suppressed mainly by an inhibition of cancer cell motility and invasiveness. ${ }^{[11,24-26]}$ As OKCs have recently been categorized as benign neoplasms with high recurrence rates as high as $60 \%,{ }^{[5,21-23]}$ an attempt was made to use immunohistochemistry for KAI-1 and p53 in the aforementioned cysts to evaluate cell proliferation and the aggressive behaviour shown by them in the present study.

In the present study, OKCs showed only $11.01 \%$ KAI-1 positivity as against radicular and dentigerous cysts, which showed $100 \%$ positivity for KAI-1. In radicular cysts, KAI-1 expression was found to have a strong and/or intermediate positivity in the epithelial lining with approximately the entire epithelial lining exhibiting KAI-1 reactivity, and it was intense in the areas of inflammation [Figure 1], indicating KAI-1 expression to be upregulated in lesions with inflammation. In dentigerous cysts, KAI-1 positivity was seen throughout the thickness of the epithelium. Staining was seen as distinct membranous or, cytoplasmic involving the epithelium lining [Figure 2] clearly evident even in the areas of minimal inflammation and places of diffuse inflammation, indicating that KAI-1 upregulation is not just a phenomenon associated with inflammation but also other factors, including the variable cytokines liberated by cystic linings. In OKCs, only $83.78 \%$ of the cases showed positivity for KAI1. Positivity was noticed in the superficial layers and tended to be focally or diffusely positive and was least in basal cell layers and suprabasal layers, which exhibited the absence of KAI-1 expression [Figure 3]. Some of the keratocystic linings in which inflammation was minimal exhibited negligible or absence of staining. Not much has been reported about the KAI-1 expression in odontogenic cysts, and there has been a paucity of studies in the literature regarding the expression of KAI-1 in the odontogenic apparatus. Extensive search revealed one study conducted by G Iezzi et al. ${ }^{[28]}$ in which the authors found a positive KAI-1 expression in radicular and dentigerous cysts but very little expression in OKCs amongst which none of the parakeratinised OKCs showed positivity and only 4 out of 16 orthokeratinised OKCs revealed KAI-1

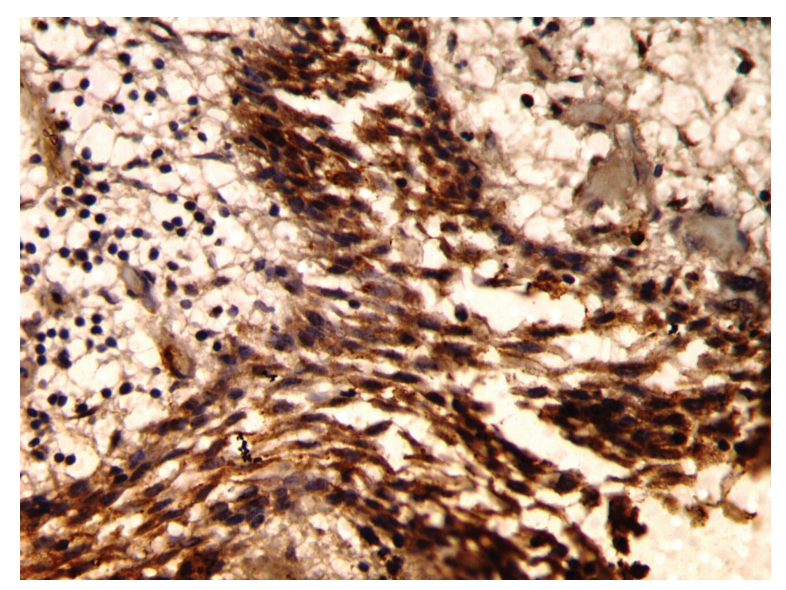

Figure 1: KAl-1 expressivity in radicular cyst $(\times 400)$ positivity. Our results are in partial agreement with their study as KAI-1 expression in dentigerous and radicular cysts were nearly comparable with their studies although OKCs exhibited KAI-1 positivity to a lesser extent.

There is a documented proof that downregulation of KAI-1 gene is associated with the increased metastasis. So, taking the reverse, also, to be true, any lesion that is benign in nature is supposed to express KAI-1, depending on the level of its aggressiveness. The term "odontogenic keratocyst" designates a cyst with a characteristic histological appearance and a specific clinical behaviour. The epithelium of OKCs is believed to have an intrinsic growth potential and shows strong evidence of being neoplastic rather than developmental origin. ${ }^{[5,21-23]} \mathrm{OKC}$ s also share the allelic loss of the same loci that have been implicated in the development of OSCCs, providing further proof for its being neoplastic in nature. ${ }^{[22,23]}$ Thus, the results of our study show that although in radicular [Figure 1] and dentigerous cysts [Figure 2], there was positivity to KAI-1, in OKCs [Figure 3], there was a significantly less expression. This lack of KAI-1 expression in OKCs could help to explain the differences in the clinical and pathological behaviour of OKCs and, according to what seems to be the pattern in several types of epithelial tumours, could be related to the increased aggressive behaviour,

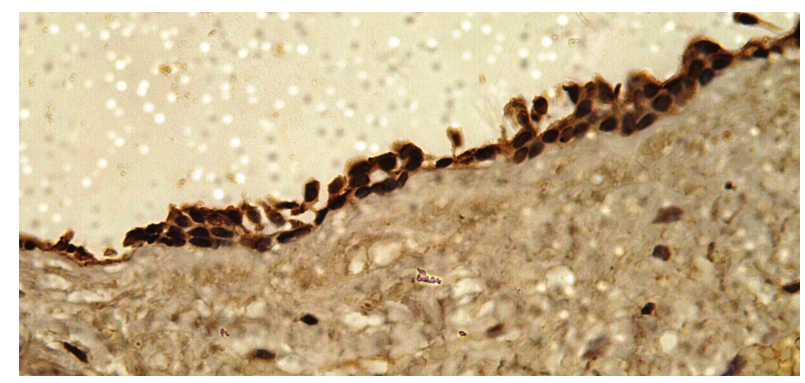

Figure 2: KAl-1 expressivity in dentigerous cyst $(\times 400)$

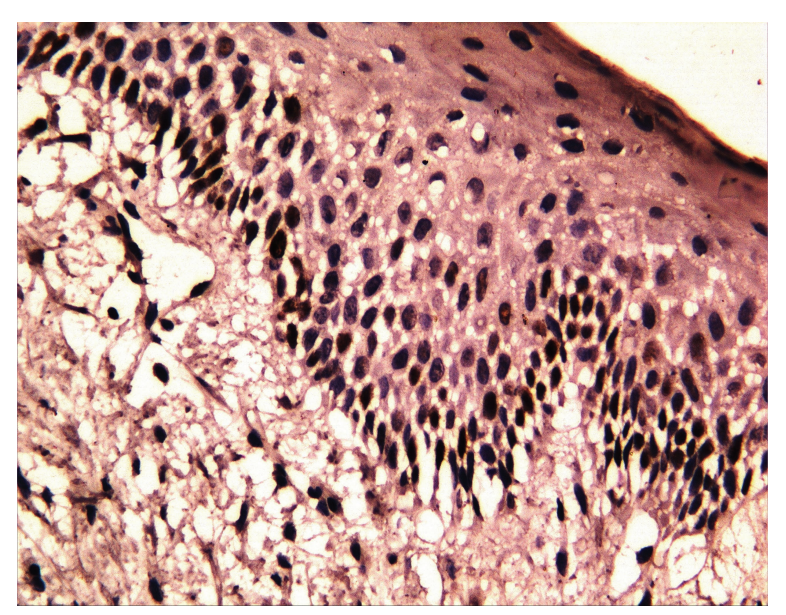

Figure 3: KAl-1 expressivity in OKC $(\times 400)$ 
invasiveness and high frequency of the recurrences found in OKCs. An increase in cell proliferation plays an important role in the development of odontogenic cysts.

p53 protein is a product of the tumour suppressor p53 gene, which functions in the G1-S phase of the cell cycle to allow repair of the damaged DNA. p53 gene has a shorter life in normal cells and cannot be detected immunohistochemically, but when mutated, p53 protein becomes more stable and detectable. Therefore, p53 protein is expressed in actively proliferating cells. While positive staining for p53 may be correlated with genetic mutation, the wild protein can also be retained in the tissues by, for example, binding to other proteins or due to some defects in the normal degradation pathway and can, therefore, be identified by immunohistochemistry. Wildtype p53 protein acting as a tumour suppressor downregulates cell growth, but mutation in p53 can inactivate its tumour suppression activity, allowing the dominant oncogenic factors to lead to malignant transformation. ${ }^{[14-18]}$

In the present study, OKCs showed $83.78 \%$ p53 positivity as against radicular and dentigerous cysts, which showed $100 \%$ positivity for p53. p53 immunolabelling was dense and scattered in the basal and suprabasal cell layers in OKCs [Figure 4], whereas very few densely stained cells were located in the basal cell layers in radicular [Figure 5] and dentigerous cysts [Figure 6] and normal oral mucosa. p53 expression was highest in OKCs [Figure 4]. In radicular [Figure 5] and dentigerous cysts [Figure 6], most of the p53 positive cells were located in basal and suprabasal cell layers. This was in agreement with the study conducted by Ogden et al. ${ }^{[29]}$, who concluded that most of the p53 positive cells were located in the basal cell layers in OKCs whereas radicular and dentigerous cysts were negative for p53. Slootweg et al. ${ }^{[30]}$ and Li TJ et al. ${ }^{[31]}$, however, reported that positive cells were detected in all odontogenic cysts, though to variable extents. The findings of the present study were in accordance with these authors as well as with the various other studies present in the literature. ${ }^{[20,26,27,32]}$

Recent studies have also indicated that p53 alteration occurs at a greater frequency in invasive than in noninvasive carcinomas. ${ }^{[15,33]}$ The high reactivity of p53 protein in OKCs

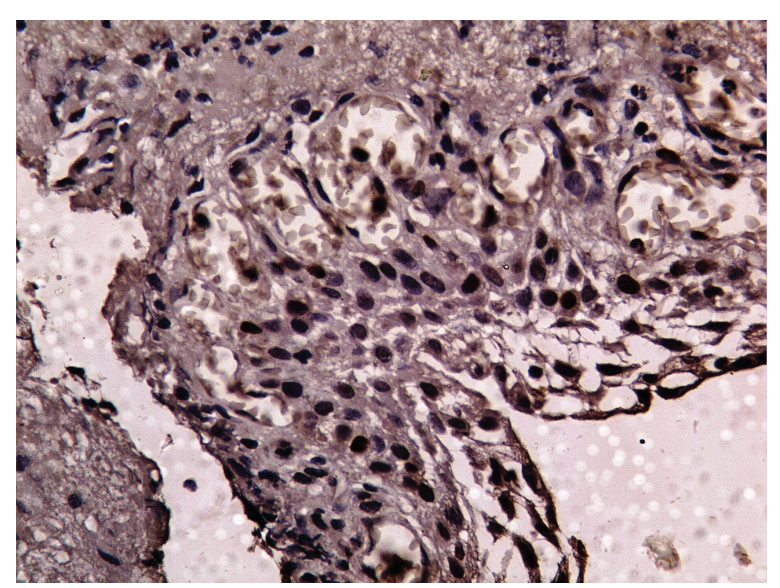

Figure 4: p53 expressivity in OKC $(\times 400)$

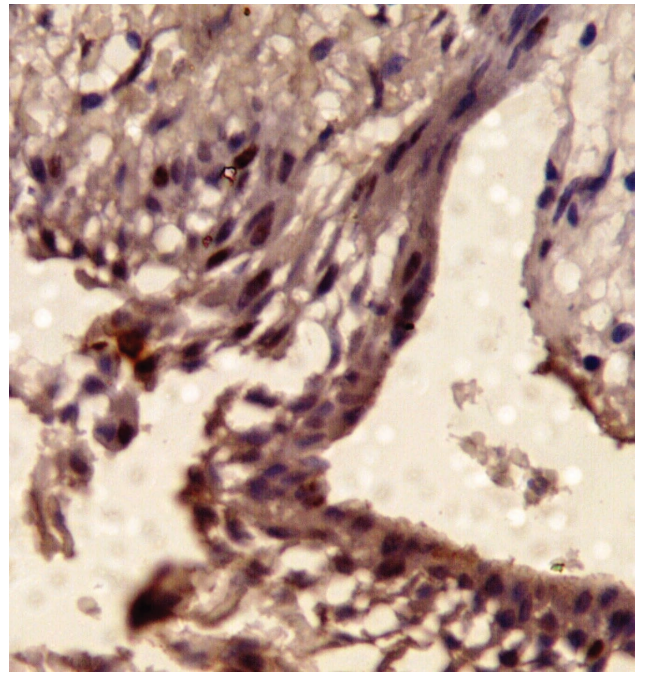

Figure 5: p53 expressivity in radicular cyst $(\times 400)$

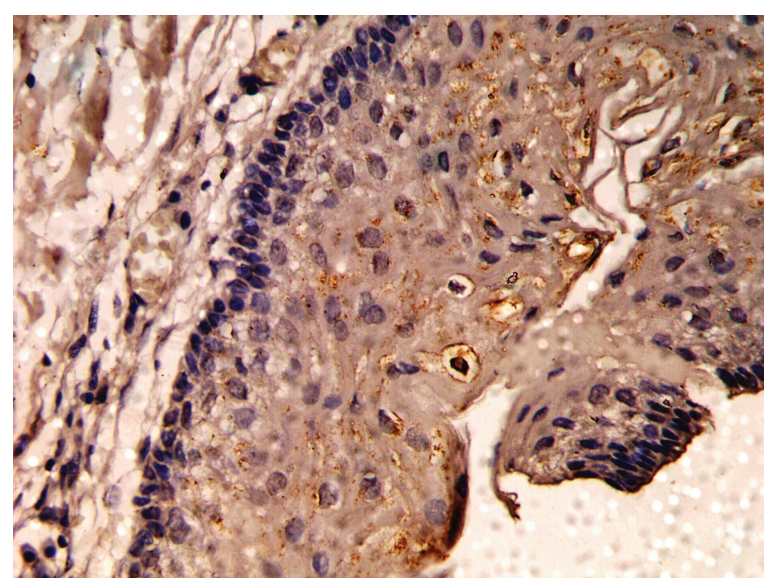

Figure 6: p53 expressivity in dentigerous cyst $(\times 400)$

could, thus, be related to the factors peculiar to extensive cystic lesions, including their locally aggressive behaviour, high mitotic activity of their cells and their tendency to recur, although the rate of recurrence might depend on the method and adequacy of their treatment. This p53 reactivity, thus, indicates the possible role it plays in the high intrinsic growth potential and biological aggressiveness of these lesions.

To conclude, amongst odontogenic cysts, radicular cysts expressed maximum positivity of KAI-1 while p53 positive cells were maximum in OKCs. The increased KAI-1 expression in radicular cysts and its downregulation in OKCs may be indicative of aggressive clinical behaviour and the fact that OKCs are hypothesised as neoplastic rather than being developmental in origin. Also, the high reactivity of $\mathrm{p} 53$ protein in OKCs could be related to the factors peculiar to extensive cystic lesions, including their locally aggressive behaviour, high mitotic activity of their cells and their tendency to recur.

Although a large body of work exists regarding the significance of p53 expression, the significance of increased or decreased 
KAI-1 expression in the aggressiveness in nonneoplastic lesions remains unclear. This study, thus, paves way for further research to investigate, if any, a correlation existing between KAI-1 and p53 expressions in odontogenic cysts and numerous other odontogenic lesions with suspect clinical behaviour as very limited studies, till date, have been conducted in this regard.

\section{Acknowledgement}

To all the patients who contributed in the study without whom this study would not have been feasible.

\section{Source(s) of Support}

None.

\section{Conflicting Interest}

None.

\section{References}

1. Shear M. Cysts of the Oral Regions. 3rd ed. Oxford: ButterworthHeinemann; 1992.

2. Shafer WG, Hine MK, Levy BM. Cysts of odontogenic origin. In: Textbook of Oral Pathology. 4th ed. Philadelphia, PA: Elsevier; 2004. p. 258-74.

3. Neville BW, Damm DD, Allen CM, Bouquot JE. Odontogenic cysts. In: Neville BW, Damm DD, Allen CM, Bouquot JE editors. Oral and Maxillofacial Pathology. 2nd ed. Philadelphia, PA: WB Saunders; 2005. p. 590-97.

4. Shear M. Odontogenic keratocyst: Natural history and immunohistochemistry. Oral Maxillofacial Sug Clin N Am 2003;15:335-45.

5. Shear M. The Aggressive nature of the odontogenic keratocyst: Is it a benign cystic neoplasm? Part 2. Proliferation and genetic studies. Oral Oncol 2002;38:323-31.

6. Blanas N, Freund B, Schwartz M, Furst I. Systemic review of the treatment and prognosis of the odontogenic keratocyst. Oral Surg Oral Med Oral Pathol Oral Radiol Endod 2000;90:553-58.

7. Kauffman E Robinson. Metastasis suppression: The evolving role of metastasis suppressor genes for regulating cancer cell growth at the secondary site. J Urol 2003;169:1122-33.

8. Wu Q, Ji Y, Zang M, Chen Y, Chen F, Shi D, et al. Role of tumor metastasis suppressor gene KAI1 in digestive tract carcinomas and cancer cells. Cell Tissue Res 2003;314:237-49.

9. Farhadieh R, Smee R, Ow K, Yang J, Russell P, Crouch R, et al. Down-regulation of KAI1/CD82 protein expression in oral cancer correlates with reduced disease free survival and overall patient survival. Cancer Lett 2004;213:91-98.

10. Imai $\mathrm{Y}$, Sasaki $\mathrm{T}$, Shinagawa $\mathrm{Y}$, Akimoto $\mathrm{K}$, Fujibayashi $\mathrm{T}$. Expression of metastasis suppressor gene (KAI1/CD82) in oral squamous cell carcinoma and its clinico-pathological significance. Oral Oncol 2002;38:557-61.

11. Liu W, Zhang X. KAI-1/CD82: A tumor metastasis suppressor. Cancer Lett 2006;240:183-94.

12. Solomon MC, Carnelio S, Gudattu V. Molecular analysis of oral squamous cell carcinoma: A tissue microarray study. Indian J Cancer 2010;47:166-72.

13. Fabbrocini G, Russo N, Pagliuca MC. p53, cyclin-D1, PCNA, AgNOR expression in squamous cell cancer of the lip: A multicenter study. Photodermatol Photoimmunol Photomed 2000;4:172-77.

14. Levine A, Finlay C, Hinds P. P53 is a Tumor suppressor gene. Cell 2004;116:67-69.
15. Matlashewski G, Banks L, Pim D, Crawford L. Analysis of human p53 protein and mRNA levels in normal and transformed cells. Eur J Biochem 1986;154:665-72.

16. Foulkes WD. p53-Master and commander. N Engl J Med 2007;357:2539-41.

17. Bradley G, Trembly S, Irish J, MacMillan C, Baker G. The expression of p53 induced protein with death domain (Pidd) and apoptosis in OSCC. Cancer Res 2007;36:415-24.

18. Shin Dong M, Lee Jin S, Lippman Scott M, Lee J Jack, Tu Z Nora, Heyne Kirk, et al. p53 Expression: Predicting recurrence and second primary tumors in head and neck squamous cell carcinoma. J Natl Cancer Inst 1996;88:519-29.

19. Chirapathomsakul D, Sastravaha P, Jansisyanont P. A review of odontogenic keratocysts and the behavior of recurrences. Oral Surg Oral Med Oral Pathol Oral Radiol Endod 2006; 101:5-9.

20. Tosios K, Angelopoulou E, Kapranos N. Immunohistochemical study of bcl-2 protein, Ki-67 antigen and p53 protein in epithelium of glandular odontogenic cysts and dentigerous cysts. J Oral Pathol Med 2000;29:139-44.

21. Shetty DC, B Aadithya, Gandhi S, Gupta S. Classifying odontogenic keratocyst as benign cystic neoplasms: A molecular insight to aggressiveness. J Maxillofac Oral Surg 2010;9:30-34.

22. Anand V, Arrowood J, Krolls S. Malignant potential of the odontogenic keratocyst. Otolaryngol Head Neck Surg 1994;111:124-29.

23. Partridge $\mathrm{M}$, Towers JF. The primodial cyst (odontogenic keratocyst): Its tumor-like characteristics and behavior. Br J Oral Maxillofac Surg 1987;25:271-79.

24. Yoshida B, Sokoloff M, Welch D, Schaeffer C. Metastasissuppressor genes: A review and perspective on an emerging field. J Natl Cancer Inst 2000;92:1717-30.

25. Tonoli H, Barrett J. CD82 metastasis suppressor gene: A potential target for new therapeutics. Trends Mol Med 2005;11:563-70.

26. Jackson P, Millar D, Kingsley E, Yardely G, Ow K, Clark S, et al. Methylation of a $\mathrm{CpG}$ island within the promoter region of the KAI-1 metastasis suppressor is not responsible for downregulation of KAI-1 expression in invasive cancers or, cancer cell lines. Cancer Lett 2000:157;169-76.

27. Oliveira G, Lluxen S, Chaves AC, Rados PV, Sant'Ana Filho M. Immunohistochemical analysis of the patterns of p53 and PCNA expression in odontogenic cystic lesions. Med Oral Patol Oral Cir Bucal 2008;13:E275-80.

28. Iezzi G, Piattelli A, Artese L, Goteri G, Fioroni M, Rubini C. KAI-1 Protein Expression in Odontogenic Cysts. J Endod 2007;33:235-38.

29. Ogden GR, Chisholm DM, Kiddie RA, Lane DP. p53 protein in odontogenic cysts: Increased expression in some odontogenic keratocyst. J Clin Pathol 1992;45:1007-10.

30. Slootweg PJ. p53 protein and Ki-67 reactivity in epithelial odontogenic lesions: An immunohistochemical study. J Oral Pathol Med 1995;24:393-97.

31. Li TJ, Browne RM, Prime SS, Paterson IC, Matthews JB. p53 expression in odontogenic keratocyst epithelium. J Oral Pathol Med 1996;25:245-55.

32. Gaballah E, Tawfik M. Immunohistochemical analysis of P53 protein in odontogenic cysts. Saudi Dent J 2010;10:1016.

33. Crosthwaite N, Teale D, Franklin C, Foster GA, Stringer BMJ. p53 protein expression in malignant, pre-malignant and non-malignant lesions of the lip. J Clin Pathol 1996: $49 ; 648-53$. 


\section{Erratum}

After the publication of this manuscript entitled "KAI-1 and p53 expression in odontogenic cysts: An immunohistochemical (IHC) marker study" it was noted that there was an error in the author sequence. The correct author sequence, names and affiliations are given below;

${ }^{1}$ Namrata N. Patil; ${ }^{2}$ Abhishek Singh Nayyar; ${ }^{3}$ Vijay Wadhwan; ${ }^{4}$ Minal Chaudhary

Department(s) and institution(s):

${ }^{1}$ Department of Oral Pathology and Microbiology, SaraswatiDhanwantari Dental College and Hospital and Post-Graduate Research Institute, Parbhani, Maharashtra, India

${ }^{2}$ Department of Oral Medicine and Radiology, SaraswatiDhanwantari Dental College and Hospital and Post-Graduate Research Institute, Parbhani, Maharashtra, India

${ }^{3}$ Department of Oral Pathology and Microbiology, Subharti Dental College and Hospital, Meerut, Uttar Pradesh, India

${ }^{4}$ Department of Oral Pathology and Microbiology, Sharad Pawar Dental College and Hospital, Wardha, Maharashtra, India 